University of Nebraska - Lincoln

DigitalCommons@University of Nebraska - Lincoln

Agronomy \& Horticulture -- Faculty Publications

Agronomy and Horticulture Department

2010

\title{
Emissions Savings in the Corn-Ethanol Life Cycle from Feeding Coproducts to Livestock
}

\author{
Virgil R. Bremer \\ University of Nebraska-Lincoln, vbremer2@unl.edu \\ Adam Liska \\ University of Nebraska-Lincoln, aliska2@unl.edu \\ Terry J. Klopfenstein \\ University of Nebraska-Lincoln, tklopfenstein1@unl.edu \\ Galen E. Erickson \\ University of Nebraska-Lincoln, gerickson4@unl.edu \\ Haishun Yang \\ University of Nebraska-Lincoln, hyang2@unl.edu
}

See next page for additional authors

Follow this and additional works at: https://digitalcommons.unl.edu/agronomyfacpub

Part of the Plant Sciences Commons

Bremer, Virgil R.; Liska, Adam; Klopfenstein, Terry J.; Erickson, Galen E.; Yang, Haishun; Walters, Daniel T.; and Cassman, Kenneth G., "Emissions Savings in the Corn-Ethanol Life Cycle from Feeding Coproducts to Livestock" (2010). Agronomy \& Horticulture -- Faculty Publications. 388.

https://digitalcommons.unl.edu/agronomyfacpub/388

This Article is brought to you for free and open access by the Agronomy and Horticulture Department at DigitalCommons@University of Nebraska - Lincoln. It has been accepted for inclusion in Agronomy \& Horticulture -Faculty Publications by an authorized administrator of DigitalCommons@University of Nebraska - Lincoln. 


\section{Authors}

Virgil R. Bremer, Adam Liska, Terry J. Klopfenstein, Galen E. Erickson, Haishun Yang, Daniel T. Walters, and Kenneth G. Cassman 


\title{
Emissions Savings in the Corn-Ethanol Life Cycle from Feeding Coproducts to Livestock
}

\author{
Virgil R. Bremer, Adam J. Liska, Terry J. Klopfenstein, and Galen E. Erickson University of Nebraska \\ Haishun S. Yang Monsanto Company \\ Daniel T. Walters and Kenneth G. Cassman* University of Nebraska
}

Environmental regulations on greenhouse gas (GHG) emissions from corn (Zea mays L.)-ethanol production require accurate assessment methods to determine emissions savings from coproducts that are fed to livestock. We investigated current use of coproducts in livestock diets and estimated the magnitude and variability in the GHG emissions credit for coproducts in the corn-ethanol life cycle. The coproduct GHG emissions credit varied by more than twofold, from 11.5 to $28.3 \mathrm{~g} \mathrm{CO}_{2}$ e per MJ of ethanol produced, depending on the fraction of coproducts used without drying, the proportion of coproduct used to feed beef cattle (Bos taurus) vs. dairy or swine (Sus scrofa), and the location of corn production. Regional variability in the GHG intensity of crop production and future livestock feeding trends will determine the magnitude of the coproduct GHG offset against GHG emissions elsewhere in the corn-ethanol life cycle. Expansion of annual U.S. corn-ethanol production to 57 billion liters by 2015 , as mandated in current federal law, will require feeding of coproduct at inclusion levels near the biological limit to the entire U.S. feedlot cattle, dairy, and swine herds. Under this future scenario, the coproduct GHG offset will decrease by $8 \%$ from current levels due to expanded use by dairy and swine, which are less efficient in use of coproduct than beef feedlot cattle. Because the coproduct GHG credit represents 19 to $38 \%$ of total life cycle GHG emissions, accurate estimation of the coproduct credit is important for determining the net impact of corn-ethanol production on atmospheric warming and whether corn-ethanol producers meet state- and nationallevel GHG emissions regulations.
Copyright $\odot 2010$ by the American Society of Agronomy, Crop Science Society of America, and Soil Science Society of America. All rights reserved. No part of this periodical may be reproduced or transmitted in any form or by any means, electronic or mechanical, including photocopying, recording, or any information storage and retrieval system, without permission in writing from the publisher.

Published in J. Environ. Qual. 39:472-482 (2010).

doi:10.2134/jeq2009.0283

Published online 6 Jan. 2010.

Received 24 July 2009.

*Corresponding author (kcassman1@unl.edu)

(1) ASA, CSSA, SSSA

677 S. Segoe Rd., Madison, WI 53711 USA
W HILE COPRODUCTS from maize grain-ethanol production are an important source of animal feed and additional income for biorefineries, coproduct production, processing, transport, and end-use also have a large impact on net GHG emissions from the corn-ethanol life cycle (Klopfenstein et al., 2008; Liska et al., 2009; Farrell et al., 2006). State and federal regulations under development will require life cycle GHG emissions from biofuels to achieve minimum reduction levels compared to transportation fuels derived from petroleum. For example, the Energy Independence and Security Act of 2007 (EISA) requires that corn-ethanol, cellulosic ethanol, and advanced biofuels reduce life cycle GHG emissions by 20,60 , and $50 \%$, respectively. Because GHG-credits for coproducts have been previously estimated to offset 19 to $38 \%$ of positive life cycle emissions from corn production and biorefining (Liska et al., 2009), it is critical that these credits are accurately estimated to determine the net anthropogenic impact of corn-ethanol production on the atmosphere. Furthermore, such knowledge should be accurately captured by life cycle assessment (LCA) methods used in the regulatory process for biofuels.

Recent changes in coproduct use as livestock feed suggest that previous estimates of coproduct credits are no longer representative of current industry practices (Klopfenstein et al., 2008; NASS, 2007). For example, recent estimates of substitution rates between coproducts and conventional feed (Arora et al., 2008) do not consider the impact of changing coproduct uses in livestock diets on the magnitude of the coproduct GHG credit, and its impact on the life cycle of corn-ethanol. Furthermore, varying rates of coproduct substitution in different livestock feeding settings requires a dynamic coproduct crediting model to determine the GHG credit attributable to each of the main livestock feeding systems.

Distillers grains plus solubles (DGS) are composed of the nonfermentable portion of corn grain and are the coproduct from dry-mill corn-ethanol production. Dry-mill biorefineries powered by natural gas currently represent nearly $90 \%$ of U.S. grain-ethanol production capacity (G. Cooper, personal communication, 2009). Corn starch fermented to ethanol represents roughly $73 \%$

V.R. Bremer, T.J. Klopfenstein, and G.E. Erickson, Dep. of Animal Science; A.J. Liska, Department of Biological Systems Engineering; H.S. Yang, Monsanto Company, 800 North Lindbergh Blvd., St. Louis, MO 63167; D.T. Walters, and K.G. Cassman, Dep. of Agronomy and Horticulture; K.G. Cassman, Nebraska Center for Energy Sciences Research, Univ. of Nebraska, Lincoln, NE 68583.

Abbreviations: DDGS, dried distillers grains with solubles; DGS, distillers grains plus solubles; GHG, greenhouse gas; LCA, life cycle assessment; WDGS, wet distillers grains with solubles. 
of grain dry matter and about $67 \%$ of the energy content. The remaining protein, lipid, cellulose, lignin, and ash make up about $27 \%$ of grain dry matter and $33 \%$ of the energy (Table $1)$. As such, the energy content of coproducts is a sizable portion of total energy output of the corn-ethanol life cycle.

Three main types of distillers grains are produced by most dry mill ethanol biorefineries (NASS, 2007). Wet distillers grains with solubles (WDGS; 65\% water) are produced by adding condensed distillers solubles back to the solid unfermentable portion of the corn grain after fermentation. Distillers solubles are the water soluble fraction of postdistillation stillage that are separated via centrifugation. An alternate product, modified distillers grains with solubles (MDGS; 55\% water) are produced when the coproduct fraction is partially dried before the condensed solubles are added. If the solubles and coproduct are mixed together and dried more completely, dried distillers grains with solubles (DDGS; 10\% water) are produced. Producing coproducts with less moisture requires energy input at the biorefinery (Liska et al., 2009).

Livestock producers use coproducts as a source of both energy and protein in beef, dairy, and swine diets. As such, they primarily substitute for corn and protein in livestock feeds (Klopfenstein et al., 2008; Schingoethe, 2008; Stein, 2008). The type of protein replaced by DGS in animal diets depends on whether beef cattle, dairy cattle, or swine are being fed, each with a distinct dietary substitution. For example, soybean meal is the major protein source replaced by DGS in dairy and swine diets (Schingoethe, 2008; Stein, 2007). In contrast, DGS substitutes for urea as a $\mathrm{N}$ source for protein in beef cattle diets (Klopfenstein et al., 2008). A nutritionist survey of beef cattle rations conducted in 2000 found urea to be the primary source of supplemental protein in feedlot systems (Galyean and Gleghorn, 2001). By 2007, however, ethanol coproducts were widely used as a low-cost protein source for feedlot cattle (Vasconcelos and Galyean, 2007).

The most widely used and accurate method for allocating coproduct GHG and energy credits to the corn-ethanol life cycle is through the displacement method in the context of "system expansion" (Kodera, 2007). This method assumes that coproducts from corn-ethanol production substitute for other feed components and offset fossil fuel use and associated GHG emissions required to produce the replaced feed components (Kodera, 2007; Liska et al., 2009). Alternative approaches to coproduct allocation include mass basis, energy content, and market value (Kodera, 2007; Kim and Dale, 2002). Although these alternative methods may be less data-intensive than the displacement method, they are not sensitive to the different livestock feeding values of corn-ethanol coproducts and therefore do not accurately represent changes in GHG emission profiles.

Estimating the displacement credit for an individual corn-ethanol biorefinery requires quantification of the different types of coproducts produced by the ethanol plant, identification of the products to be displaced in livestock diets (and displacement ratios), and calculation of the fossil fuel energy and GHG emissions attributable to the life cycle production of the displaced products (Wang, 1999; Graboski,
2002). Recent coproduct credit estimates assumed DGS displaced corn, urea, soybean meal, and oil, at a $15 \%$ inclusion level in feedlot cattle diets, as well as other variable substitutions (Kodera, 2007; Graboski, 2002; NRC, 2000).

The purpose of our study was to evaluate recent changes in livestock diets due to widespread availability and use of DGS in livestock rations, and to determine the impact of current practices on the GHG emissions mitigation potential from corn-ethanol compared to gasoline. The results of this life cycle assessment were used to understand how coproduct feed practices will influence GHG emissions of corn-ethanol relative to emissions regulations in state low carbon fuel standards (LCFS) and federal EPA standards stipulated in the EISA of 2007.

\section{Materials and Methods Coproduct Use in Beef Cattle Diets}

Data on coproduct use in feedlot cattle systems were obtained from a recent meta-analysis (Klopfenstein et al., 2008). Coproduct performance in beef cattle diets was estimated from the gain-to-feed ratios that result from inclusion of DGS in feed rations. It is noteworthy that the Klopfenstein study documented improved performance of DDG when substituted for corn, and an additional benefit of WDGS compared to DDGS. Moreover, the feeding value of each type of coproduct is modulated by the proportion of substitution in the diet. Hence, the type and level of DGS fed determine cattle performance. A detailed biological model, based on the coproduct feeding trials of Klopfenstein et al. (2008), has been developed as a component of the Biofuel Energy Systems Simulator (BESS model, www.bess.unl.edu) to estimate animal performance and protein replacement from DGS substitution in conventional feedlot diets.

Experimental data have demonstrated that up to $50 \%$ of diet dry matter may be replaced with DGS in feedlot diets and improve cattle performance (Klopfenstein et al., 2008). Nutritionists' surveys indicate the current average coproduct inclusion rate is $20 \%$ (dry matter basis) with a range of 5 to $50 \%$ of the diet (Vasconcelos and Galyean, 2007). In the Corn Belt, survey data suggest that beef producers feeding DGS
Table 1. Biomass and energy characteristics of corn grain.

\begin{tabular}{|c|c|c|c|c|}
\hline & $\begin{array}{c}\text { Grain } \\
\text { composition }\end{array}$ & $\begin{array}{l}\text { Energy } \\
\text { densityt }\end{array}$ & $\begin{array}{l}\text { Energy } \\
\text { amount }\end{array}$ & $\begin{array}{l}\text { Energy } \\
\text { fraction }\end{array}$ \\
\hline & $\mathrm{kg} \mathrm{kg}^{-1}$ & $\mathrm{MJ} \mathrm{kg}^{-1}$ & MJ & $\%$ \\
\hline Starch $\ddagger$ (to ethanol) & 0.726 & 16 & 11.6 & 66.6 \\
\hline \multicolumn{5}{|l|}{ Coproducts } \\
\hline Protein $\neq$ & 0.088 & 25 & 2.3 & 12.6 \\
\hline Lipid‡ & 0.042 & 39 & 2 & 9.4 \\
\hline Cellulose§ & 0.090 & 16 & 1.3 & 8.3 \\
\hline Lignin§ & 0.022 & 25 & 0.3 & 3.2 \\
\hline Ash§ & 0.016 & 0 & 0 & 0 \\
\hline Coproduct total & 0.258 & 22.69 & 5.8 & 33.4 \\
\hline
\end{tabular}

† Loomis and Connor (1998).

¥ Nebraska Corn Board (2008).

$\S N R C$ (2000).

I Proportion-weighted energy content of distillers grains. Based on the ethanol yield per unit grain (Table 3), at $418 \mathrm{~L}$ of ethanol per $\mathrm{Mg}$ grain, $13.9 \mathrm{MJ}$ of energy per liter of ethanol would be contained in the coproducts. 
have an average dietary inclusion of 22 to $31 \%$ on a wet basis (approximately 15-20\% of dry matter) (NASS, 2007).

Respondents to both a feedlot nutritionist survey (Vasconcelos and Galyean, 2007) and a Nebraska feedlot industry survey (Waterbury et al., 2009) reported that DGS are the most common ethanol coproduct used by cattle feeders. The Nebraska survey indicates 53 and 29\% of Nebraska feedlots feed WDGS and MDGS, respectively. The nutritionist survey indicated 69\% of the 29 nutritionists were feeding DGS as the primary coproduct in the diet, and these beef nutritionists were responsible for formulating diets for nearly $70 \%$ of cattle on feed in the United States. Results from the two surveys document that DGS are the primary coproduct used from corn-ethanol production. Therefore, DGS use in livestock rations represents the basis for estimating the coproduct credit in corn-ethanol life cycle energy and GHG assessments.

Feeding values of the DGS coproducts relative to corn were calculated for each feedlot inclusion level of wet, modified, and DDGS from measured biological feed efficiency values. These feeding values decrease as the level of coproduct increases in the diets. Thus, as more DGS are included in the diet, they replace less corn per unit increase in the substitution rate. In addition, the relative feeding value of DDGS declines at a faster rate than WDGS as inclusion levels increase, indicating that WDGS have a higher feeding value than DDGS. Based on these differences in the amounts of urea and corn substituted by coproduct relative to traditional corn-fed cattle, the resulting energy and emissions savings are calculated. When the level of coproduct fed in the diet replaces all urea, the excess coproduct protein is not credited to urea replacement. Energy use to produce urea is conservatively assumed to have come from natural gas (see BESS User's Guide, www.bess.unl.edu).

\section{Coproduct Use in Dairy Cattle Diets}

A recent meta-analysis of dairy feed rations includes data from numerous research trials to estimate current DDGS feeding practices for dairy production (Schingoethe, 2008). The nutrient composition of DGS makes it a good energy and protein source for dairy cows, and diets fed to dairy cows may contain DGS to replace corn, protein, and forages (Janicek et al., 2008). It is more common, however, to replace corn and protein without replacing forage (Schingoethe, 2008). Results from published feeding studies are not consistent with regard to dairy cow milk production response to DGS inclusion. Some studies found no change in milk production when DGS were added to lactating dairy cow diets (Schingoethe et al., 1999). Other studies reported a dilution of milk components when DGS were fed (Leonardi et al., 2005; Nichols et al., 1998), or an increase in milk production from feeding DGS (Anderson et al., 2006; Kleinschmit et al., 2006). When all available research data were combined and evaluated in a meta-analysis, no production response to DGS feeding is evident, and milk composition was not affected by substituting DGS for corn.

In the BESS model, DGS are assumed to directly replace corn and soybean meal in lactating dairy cow diets. Distillers grains had been fed up to $30 \%$ of diet dry matter to lactating dairy cows without negative affects on milk production when replacing corn and soybean meal (Schingoethe, 2008). Survey data suggest that the average inclusion of DGS in dairy diets is
10 to $22 \%$ (approximately $10 \%$ of dry matter) (NASS, 2007). At this relatively low inclusion level, DGS are primarily used as a protein supplement to replace soybean [Glycine max (L.) Merr.] meal. Based on these data, the coproduct credit for DGS inclusion in dairy cow diets in the BESS model is based on the direct replacement of corn and soybean meal at a rate of 0.45 $\mathrm{kg}$ of corn and $0.55 \mathrm{~kg}$ of soybean meal dry matter for each kilogram of DGS dry matter added to the diet (Schingoethe et al., 1999; Kleinschmit et al., 2006; Anderson et al., 2006).

\section{Coproduct Use in Swine Diets}

A recent review of swine research on feeding DDGS to finishing pigs is based on numerous studies (Stein, 2008). Finishing pigs are the main class of swine to use DDGS, and their feeding performance is not affected when DDGS replace a portion of corn and soybean meal in the diet. While this was the case in the majority of experiments, there were a few examples where reduced performance was observed when DDGS were fed. The reduced performance may result from suboptimal diet formulation, the use of low-quality DDGS, or decreased palatability of DDGS diets to the pigs (Stein, 2008). Research has shown that DDGS may be included in grow-finish diets up to $27 \%$ of diet dry matter without decreasing animal performance. When DDGS are added to swine diets, corn and soybean meal are replaced at the rate of $0.57 \mathrm{~kg}$ of corn and $0.43 \mathrm{~kg}$ of soybean meal dry matter per kilogram of DDGS dry matter (Stein, 2007).

Survey data indicate relatively few swine operations use DDGS, and the average inclusion rate is $9 \%$ of diet dry matter (NASS, 2007). Because commercial swine feeding systems are developed to deliver dry feed $(<15 \%$ moisture) to finishing pigs, feeding WDGS has logistical challenges for use in these large-scale swine operations. Hence, to our knowledge, WDGS have not been studied for swine production.

\section{Coproduct Use in Poultry Diets}

The poultry industry is an insignificant consumer of DGS based on the most recent survey (NASS, 2007). Therefore, DGS use by poultry was not included in our analysis.

\section{Current and Future Coproduct Use in Livestock Diets}

A recent NASS survey of beef, dairy, and swine operations reported ethanol coproduct use for livestock feed in the U.S. Corn Belt (NASS, 2007). In 2006, the region contained 11.3 million cattle in 1000+ head feedlots, 3.2 million dairy cattle, and 64.1 million grow-finish pigs representing 50, 33, and $70 \%$ of U.S. beef, dairy, and pork production, respectively (Table 2; NASS, 2008). The survey reported that 36,38 , and $12 \%$ of Corn Belt beef, dairy, and swine operations, respectively, were feeding coproducts in 2006. Estimating average corn-ethanol coproduct use, however, may be misleading when based on number of operations using coproducts. The data indicated that large-scale producers were more likely to use coproduct feeding (NASS, 2007; Waterbury et al., 2009). Adjusting for operation size based on coproduct use (NASS, 2007, 2008), 63, 49, and 40\% of finishing beef, dairy cows, and finisher pigs in the Corn Belt, respectively, were fed coproduct in 2006. These coproduct use numbers are representative of the major DGS producing region 
of the United States. Distillers grains utilization numbers would likely be different in other regions of the United States, and relatively little corn-ethanol is produced outside the Corn Belt. Total coproduct use by each livestock class was calculated by the dietary inclusion of DGS based on data from experiments feeding coproducts and survey data (Klopfenstein et al., 2008; Schingoethe, 2008; Stein, 2008; NASS, 2007). Three future feeding scenarios were developed based on coproduct inclusion in livestock diets and different levels of industry use (Table 2).

\section{Modeling Life Cycle Credits from Coproduct Feeding}

Energy and GHG emissions credits from the feeding of coproducts to livestock were evaluated using the BESS model, version 2009.4.0 (www.bess. unl.edu). The corn and ethanol production components of this model have been previously described, including a coproduct crediting model based solely on use in beef cattle diets (Liska et al., 2009). The update of the BESS model reported here includes a more accurate depiction of DGS use by the beef, dairy, and swine industries to estimate the coproduct credit. Other relatively minor changes (such as higher lime application rates, and electricity emissions factors [Liska and Cassman, 2009]) have also been updated and are described in the BESS User's Guide 2009.4.0 (www. bess.unl.edu). State average lime rates were applied for state level scenarios. The Midwest average electricity emission factor was applied for all scenarios.

The cattle, dairy, and swine industries are assumed to operate independently of the biofuel industry because there is no evidence that livestock numbers have been affected by expansion of the biofuel industry. In fact, the U.S. beef cow herd size decreased by $1 \%$ from 2004 to 2008 (NASS, 2008). Coproduct credits are determined for both energy and GHG emissions, based on a partial budget for livestock production operations that considers the difference between a conventional diet and a diet containing DGS. The model then estimates the energy and GHG emissions that result from production, processing, and transport of the feed products that were replaced by DGS.

\section{Credits from Hauling Coproducts}

There are no data available on the relative difference in transportation distances for corn and DGS delivery to livestock feeding operations. We therefore estimated these distances based on our knowledge of feedlot, corn, and DGS spatial relaproduction capacity.
Table 2. Midwest livestock coproduct use in 2006, potential feeding scenarios for differing

\begin{tabular}{lcccc}
\hline \multicolumn{4}{c}{ U.S. Midwest livestock industry characteristics, +2006} & \\
\hline \multicolumn{1}{c}{ Livestock classes } & Beef & Dairy & Swine & Total \\
\hline Corn Belt production, million head & 11.3 & 3.2 & 64.1 & 78.6 \\
Corn Belt production, \% of United States & 50 & 33 & 70 & - \\
Operations feeding coproduct, \% of Corn Belt & 36 & 38 & 12 & - \\
Fraction of herd fed coproduct, \% of herd & 63 & 49 & 40 & -
\end{tabular}

Current and projected feeding scenarios

Midwest industry use, 2006 (34 million head fed DGS)

\begin{tabular}{|c|c|c|c|c|}
\hline Dietary DGS inclusion level, \% of dietary intact & 20 & 10 & 9 & - \\
\hline Total DGS use, million Mg, ( $\%$ inclusion $\times$ total fed cattle) & 2.4 & 1.3 & 0.6 & 4.3 \\
\hline Distribution of DGS use, \% of total & 56 & 30 & 14 & 100 \\
\hline Ethanol industry to supply DGS, Billion $L \mathrm{yr}^{-1}$ & 3.4 & 1.9 & 0.9 & 6.2 \\
\hline \multicolumn{5}{|c|}{ Theoretical biological maximum coproduct inclusion levels (BMCIL) (34 million head) } \\
\hline Dietary DGS inclusion level, \% of dietary intact & 45 & 30 & 27 & - \\
\hline DGS use, Million Mg of dry matter & 5.5 & 3.9 & 1.9 & 11.3 \\
\hline Distribution of DGS use, \% of total & 48 & 35 & 17 & 100 \\
\hline Ethanol industry to supply DGS, Billion $L \mathrm{yr}^{-1}$ & 7.7 & 5.6 & 2.7 & 16.0 \\
\hline \multicolumn{5}{|c|}{ Theoretical complete Midwest industry adoption at BMCIL (79 million head) } \\
\hline Dietary DGS inclusion level, \% of dry matter & 45 & 30 & 27 & - \\
\hline DGS use, Million Mg of dry matter & 8.6 & 8.1 & 4.7 & 21.4 \\
\hline Industry DGS use, \% of total & 40 & 38 & 22 & 100 \\
\hline Ethanol industry to supply DGS, Billion $L \mathrm{yr}^{-1}$ & 12.2 & 11.4 & 6.6 & 30.2 \\
\hline \multicolumn{5}{|c|}{ Theoretical complete U.S. industry adoption at BMCIL (124 million head) } \\
\hline Dietary DGS inclusion level, \% of dry matter & 45 & 30 & 27 & - \\
\hline DGS use, million Mg of dry matter & 17.3 & 24.4 & 6.7 & 48.4 \\
\hline Industry DGS use, \% of total & 36 & 50 & 14 & 100 \\
\hline Ethanol industry to supply DGS, Billion $\mathrm{L} \mathrm{yr}^{-1}$ & 24.5 & 34.5 & 9.5 & 68.5 \\
\hline
\end{tabular}

† Historical Midwest feedlot cattle marketed from 1000+ head feedyards, lactating dairy cows, and -finish pig livestock numbers and the DGS use survey (NASS, 2008) are presented as the base scenario of Midwest industry use in 2006. The theoretical biological maximum coproduct inclusion tion at BMCIL assumes that all animals in the Midwest region are fed maximum inclusion of DGS. The theoretical complete U.S. industry adoption at BMCIL assumes that all U.S. beef feedlot cattle, finishing swine, and lactating dairy cows are fed maximum inclusions of DGS.

tionships. Energy and GHG estimates for transportation are based on a loaded truck transporting a payload of $22,680 \mathrm{~kg}$ with a fuel efficiency of $2.55 \mathrm{~km} \mathrm{~L}^{-1}$ per average round trip. For feedlot cattle, corn is assumed to be sourced from nearby farmers or grain elevators with a $24 \mathrm{~km}$ average haul distance; average DGS haul distance is assumed to be $48 \mathrm{~km}$. Corn and DGS haul distances are assumed to be the same when the feeds are fed to dairy and swine. Feed truck fuel used to feed cattle within the feedlot is based on $0.011 \mathrm{~L}$ diesel fuel per head per day for a traditional corn-based diet. Urea and diesel fuel energy and GHG parameters were previously described (Liska et al., 2009; see BESS 2009.4.0 User's Guide, www.bess.unl. edu). Fuel used to haul coproduct to the feedlot is calculated from the amount of coproduct fed, the haul distance, truck load size, and truck fuel efficiency. Water in WDGS requires more energy for transportation to feedlots compared to an equivalent amount of feed on a dry matter basis from DDGS or corn grain.

All of the energy and GHG emissions associated with DGS transportation are accounted for in the feedlot partial budget. Dairy and swine models are based on direct replacement of 
corn and soybean meal by DDGS; transportation fuel use for moving coproduct to the livestock operation and within the operation is assumed to be equivalent to the corn and soybean meal it replaces. When DGS diets improve cattle performance relative to traditional corn-based diets, finished cattle are on feed fewer days, feed is hauled fewer days, and a credit is given to the system for the fuel saved for not hauling the corn that the coproduct replaced. A debit is given to the system for the fuel expended to feed DGS.

\section{Greenhouse Gas Emissions from Crop Production, Nitrogen, and Enteric Fermentation}

The cropping system component of the BESS model estimates the energy and GHG emissions intensity of corn production (Liska et al., 2009). The efficiency of state-level corn production was calculated using previously defined parameters such as crop yields, fertilizer use, and fossil fuel use (Liska et al., 2009). Soybean meal emissions savings and production parameters were taken from Hill et al. (2006). Nitrous oxide $\left(\mathrm{N}_{2} \mathrm{O}\right)$ emissions for soybean and corn production were determined using IPCC guidelines which are sensitive to the amount of applied $\mathrm{N}$ and the total amount of $\mathrm{N}$ in crop residues returned to soil (IPCC, 2006). Crop residue yields were estimated for corn and soybean based on average grain yields and average ratios of grain to above- and belowground crop biomass, and the $\mathrm{N}$ concentration in these tissues.

For cattle, DGS inclusion in diets improves growth rates and thus reduces time in the feedlot for finished cattle by several days depending on the inclusion level and whether the DGS are fed dry or wet (see above). Less time in the feedlot for finished cattle reduces fuel use for transportation of feed as well as methane emissions from cattle enteric fermentation. These savings are included in the coproduct credit for the portion of DGS fed to cattle.

Enteric methane production is calculated from cattle size, projected dry matter intake, and energy content of the diet. Feed inputs are used to calculate gross energy intake by the cattle with standard animal energy equations (NRC, 1996). An average $2.9 \%$ of gross energy is lost as enteric fermentation methane by feedlot cattle (see BESS 2009.4.0 User's Guide, www.bess.unl.edu). Due to lack of data on comparison of enteric methane production from DGS vs. corn-based diets, the two feedstuffs were given the same methane production potential on a dry matter basis.

\section{Corn-Ethanol Biorefinery Energy Efficiency and Coproduct Processing}

To determine the impact of different feeding practices on the corn-ethanol life cycle, a standard natural gas-powered dry mill biorefinery is assumed in all scenarios. Data on energy use for coproduct processing were obtained from survey information provided by ethanol biorefineries of this type operating in 2006-2007. Subsets of the data from these surveys have been previously reported (Perrin et al., 2009; Liska et al., 2009) and data were obtained directly from the plant managers. The surveyed biorefineries were located in Iowa, Michigan, Minnesota, Missouri, Nebraska, South Dakota, and Wisconsin. For the nine biorefineries, the date of initial operation included $2001(n=1$, with plant expansion in 2007), $2004(n=1$, expansion in 2006), $2005(n=6)$, and $2006(n=1)$. All yield and efficiency values are for anhydrous ethanol. Only aggregate data are shown to maintain confidentiality of individual biorefineries. Average yields and efficiencies were weighted by production capacities of biorefineries in the survey. Plant capacities represented a total production capacity of 1.83 billion L in 2006 (485 million gallons), which was about $10 \%$ of total U.S. corn-ethanol production in 2006.

The relationship between biorefinery energy use and production of the different coproduct types was determined by least squares regression based on the above survey data (Table $3)$. The data at the bottom half of the table were used to determine an equation to estimate total natural gas use $\left(\mathrm{MJ} \mathrm{L}^{-1}\right.$ ethanol) at the biorefinery when producing different fractions of coproducts for use in Table 4; total $\mathrm{MJ} \mathrm{L}^{-1}=3.42 \mathrm{MJ} \mathrm{L}^{-1} \times$ $\%$ DDGS + 1.64 MJ L $\mathrm{L}^{-1} \times \% \mathrm{MDGS}+4.91 \mathrm{MJ} \mathrm{L}^{-1}$. Ethanol yields above are for $100 \%$ biofuel; $3 \%$ of the volume of the ethanol yield in the survey data was removed for exclusion of denaturant, based on statistics from the Nebraska Department of Environmental Quality that show an average denaturant level of $2.7 \%$ in 2007 in Nebraska.

\section{Scenarios for Coproduct Production and Feed Substitution in the Corn-Ethanol Life Cycle}

Twelve scenarios were developed to represent current coproduct production and livestock feeding practices to evaluate DGS use (Table 4). These scenarios provide the basis for estimating energy and GHG credits from coproducts in corn-ethanol systems. The DGS credit was evaluated based on the distribution of coproduct use between the beef, dairy, and swine industries (MWavg, MWdav, IAavg, NEavg, TXavg, MWfav), or only one type of coproduct was assumed to be produced and fed to one type of livestock (NEdb, NEmb, NEwb, MWds, MWdd, MWdb). The six single coproduct scenarios are hypothetical, as well as Midwest dry average (MWdav) and Midwest future average (MWfav). Corresponding feed substitutions were determined based on livestock type, coproduct type, and inclusion level.

\section{Coproduct Composition}

Scenario MWavg is based on livestock data in Table 2 and assumes swine are fed only DDGS, dairy use is 70,15 , and

Table 3. Performance of new natural gas powered dry mill biorefineries (nine in survey).

\begin{tabular}{lcc}
\hline \multicolumn{1}{c}{ Parameter } & Avg. \pm SD & Range \\
\hline Ethanol capacity, million $\mathrm{L} \mathrm{yr}^{-1}$ & $198 \pm 20$ & $175-243$ \\
Ethanol yieldt, $\mathrm{L}$ ethanol $\mathrm{Mg}^{-1}$ & $418 \pm 10$ & $404-432$ \\
Electricity, $\mathrm{kWh} \mathrm{L}^{-1}$ ethanol & $0.176 \pm 0.043$ & $0.145-0.268$ \\
DGS production rate, $\mathrm{kg} \mathrm{L}^{-1}$ ethanol & $0.632 \pm 0.043$ & $0.59-0.71$ \\
Natural gas (total use), $\mathrm{MJ} \mathrm{L}^{-1}$ ethanol & $7.72 \pm 0.57$ & $6.80-8.41$ \\
Natural gas used for drying DGS, \% & $36 \pm 9.5$ & $17-47$ \\
Natural gas (boiler), MJ L-1 ethanol & $4.91 \pm 0.62$ & $3.61-5.75$ \\
Natural gas (drying), MJ L-1 ethanol & $2.81 \pm 0.81$ & $1.18-3.82$ \\
DDGS, \% of production & $67 \pm 35$ & $0-98$ \\
MDGS, \% of production & $32 \pm 36$ & $0-100$ \\
WDGS, \% of production & $1 \pm 2$ & $0-5$ \\
\hline
\end{tabular}

† Anhydrous ethanol yield is relative to grain at $15.5 \%$ moisture. 


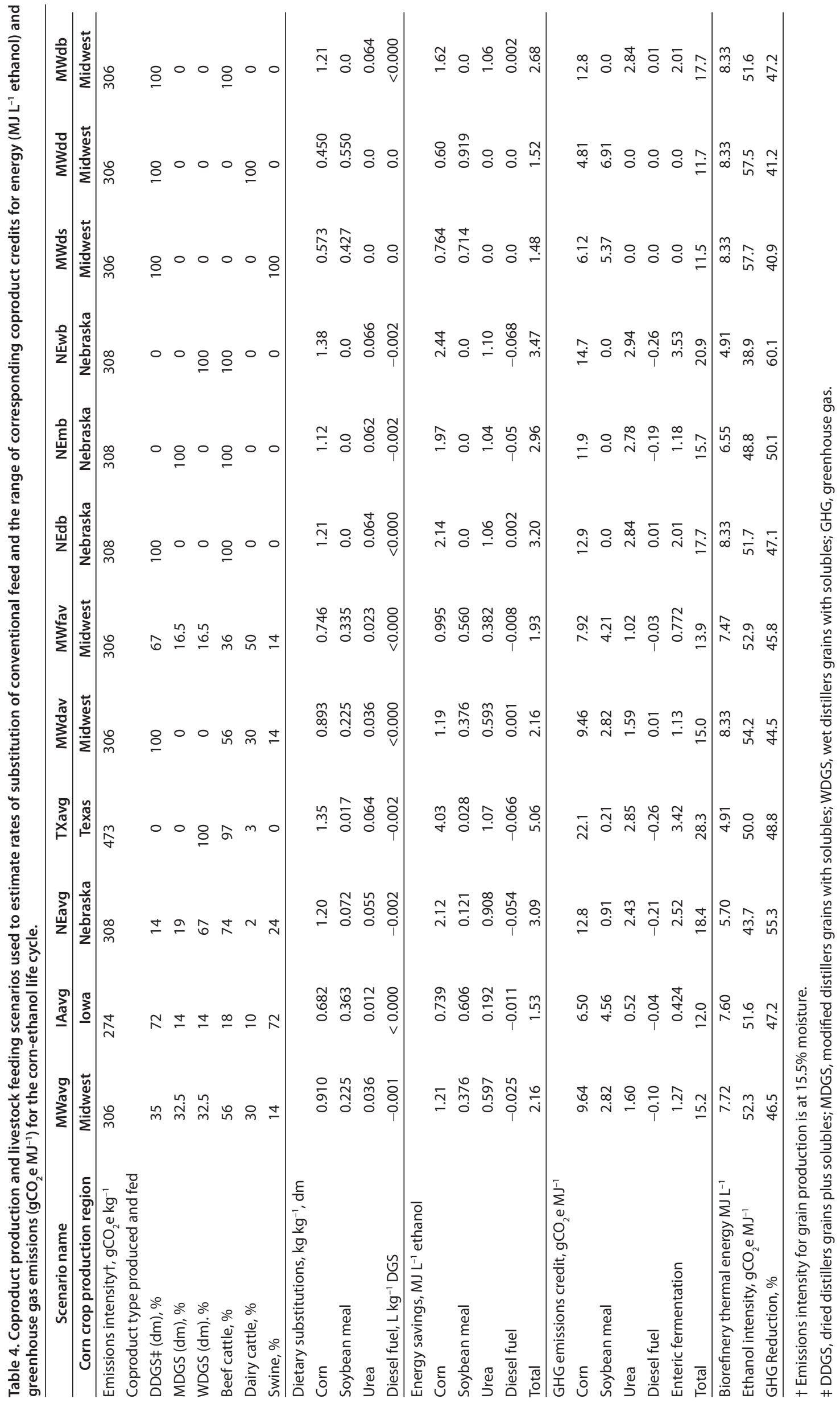


15 for, DDGS, MDGS, and WDGS, respectively, and beef use is $50 \%$ of both MDGS and WDGS. IAavg is based on livestock data, where all swine use DDGS, and beef and diary are equally split between MDGS and WDGS. NEavg coproduct production data are from 14 natural gas powered dry-mill biorefineries in Nebraska in 2007 (based on data from air emissions inventories, the Nebraska Department of Environmental Quality). TXavg is based on livestock data (below) and assumes all Texas DGS are produced wet due to large cattle numbers in close proximity to operating ethanol plants.

\section{Livestock Class Composition}

Livestock distribution is based on a survey of coproduct use and livestock production in the Midwest (MWavg, MWdav) (NASS, 2007, 2008), and recent surveys of the livestock industry in Iowa, Nebraska, and Texas (IAavg, NEavg, TXavg, respectively) (NASS, 2009). The IAavg calculations are based on Census of Agriculture numbers (NASS, 2008), livestock industry survey (Lain et al., 2008), and industry experts (M. Brumm, personal communication, 2009; L. Kilmer, personal communication, 2009). NEavg calculations are based on Census of Agriculture numbers (NASS, 2009), livestock industry survey (Waterbury et al., 2009), and industry experts (P. Kononoff, personal communication, 2009; D. Reese, personal communication, 2009). The TXavg calculations are based on Census of Agriculture numbers (NASS, 2009), and the remaining scenarios used hypothetical livestock class compositions as described.

Coproduct inclusion rates for all scenarios are 20,9, and $10 \%$ of diet dry matter for beef, swine, and dairy, respectively. Dietary substitutions, energy, and GHG credits were determined using the BESS model version 2009.4.0 (www.bess.unl. edu). The MWfav scenario is the projected future DGS use based on Table 2.

\section{Results}

\section{Substitutions in Livestock Diets and Greenhouse Gas Emissions Reductions}

The beef finishing industry was found to be the major user of DGS with $56 \%$ of Corn Belt DGS fed to feedlot cattle on a dry matter basis. The Corn Belt dairy and swine industries use 30 and $14 \%$ of total DGS production, respectively. These three livestock classes account for 4.4 million Mg of Corn Belt DGS use, which is sufficient DGS demand to support 6.2 billion $\mathrm{L}$ annual ethanol production at current levels of inclusion in feed rations (Table 2). This estimate is conservative, however, because feedlot cattle numbers are based on NASS data that are only collected for feedlots greater than 1000 head; small farmer-feeders are not included. Other exclusions are calves and cows on grass, dairy heifers and nonlactating dairy cows, and sow and sow development animals that are given DGS as a nutritional supplement or feed component. In addition, there is a small amount of DGS fed to poultry, and some of the DGS is exported to other countries, both of which are not included in these estimates.

In livestock feeding systems, the coproduct energy credit for the corn-ethanol life cycle is determined by the amount of fossil fuels offset from the production of substituted feeds (which is much lower than the energy derived from combustion; Tables 1 and 4). The Midwest average scenario is based on average coproduct production and feeding a weighted average of DGS fed to cattle, dairy, and swine in the Midwest (MWavg). In this scenario, $1 \mathrm{~kg}$ of DGS dry matter replaces $0.91,0.23$, and $0.04 \mathrm{~kg}$ of corn, soybean meal, and urea, respectively (Table 4). Comparable average DGS replacement values were recently reported by Arora et al. (2008). These average values mask large differences in replacement values depending on types of coproduct produced and how they were fed to different livestock classes. For example, substitutions were found to range from 0.45 to $1.35 \mathrm{~kg}$ for corn, 0 to $0.55 \mathrm{~kg}$ for soybean meal, and 0 to $0.07 \mathrm{~kg}$ for urea across WDGS, DDGS, and MDGS fed to cattle, dairy, or swine (Table 4). Energy and GHG emissions credits for the corn-ethanol life cycle are based on the above substitution rates. Dairy and swine GHG credits are calculated from the direct offset of energy inputs and associated emissions for the production of corn and soybean meal.

\section{Greenhouse Gas Emissions Credits and Cropping Emissions Intensity}

The Midwest average energy credit for ethanol was determined to be $2.16 \mathrm{MJ}$ per liter, with replacement of corn, urea, and soybean meal accounting for roughly 56,28 , and $17 \%$ of the energy credit, respectively (MWavg, Table 4). Due to the multispecies approach of this coproduct model, the aggregate value is less than the $4.13 \mathrm{MJ} \mathrm{L}^{-1}$ of ethanol previously reported by Farrell et al. (2006). In terms of GHG emissions, corn, soybean meal, urea, and enteric fermentation account for 63, 19, 11 , and $8 \%$, respectively, of the credit in the Midwest average scenario, with minimal impact on diesel fuel use. The average Midwest GHG credit was $15.2 \mathrm{~g} \mathrm{CO}_{2}$-eqiuivalent $\left(\mathrm{gCO}_{2} \mathrm{e}\right)$ per $\mathrm{MJ}$ of ethanol produced.

The corn substituted by DGS is assumed to be produced locally. Because each state has a different efficiency of crop production, energy and GHG emissions credits were determined by the average emissions from crop production for the state in which the biorefinery is located (Liska et al., 2009). Based on state-level data, the GHG emissions credit increases with the GHG emissions intensity of the cropping system used to produce the grain for coproducts (Fig. 1). For example, corn GHG production intensity in Iowa (274 $\left.\mathrm{gCO}_{2} \mathrm{e} \mathrm{kg}^{-1}\right)$ is lower than Nebraska efficiency $\left(308 \mathrm{gCO}_{2} \mathrm{e}\right.$ $\mathrm{kg}^{-1}$ ) because 70 to $75 \%$ of total corn production in Nebraska comes from irrigated systems that require energy inputs for irrigation. Texas corn production $\left(473 \mathrm{gCO}_{2} \mathrm{e} \mathrm{kg}^{-1}\right)$ has lower average crop yields, greater nutrient inputs, and more irrigation than Iowa. The Midwest corn production efficiency is the weighted average of 12 Corn Belt states and has an emissions intensity of $306 \mathrm{gCO}_{2}$ e per kg grain. In states like Iowa, $\mathrm{N}_{2} \mathrm{O}$ emissions account for half of the net emissions from corn production based on IPCC Tier I calculations (Liska et al., 2009; IPCC, 2006). The GHG credit in Iowa, Nebraska, and Texas (IAavg, NEavg, TXavg) was found to range from 12.0 to $28.3 \mathrm{gCO}_{2} \mathrm{e} \mathrm{MJ}^{-1}$, which incorporates state differences in GHG intensity of both crop and DGS production, and the use of DGS across the three categories of livestock (Table 4, 
Fig. 1). While we realize that a significant portion of the corn use by livestock and ethanol biorefineries in Texas is sourced from Corn Belt states, which are more energy and GHG efficient in corn production than Texas, our analysis assumed the corn for a Texas biorefiinery is obtained from local sources.

\section{Evaluation of Individual Types of Coproducts and Livestock}

Feeding scenarios in which only one type of coproduct is produced by the biorefinery and used to feed one type of livestock were examined for the Midwest average and Nebraska cropping systems to evaluate the impact of drying and feeding efficiency on the GHG credit (Table 4). In these scenarios the energy credit ranged from 1.48 to $3.47 \mathrm{MJ} \mathrm{L}^{-1}$ of ethanol while the GHG emissions credit ranged from 11.5 to $20.9 \mathrm{gCO}_{2} \mathrm{e} \mathrm{MJ}^{-1}$ (Table 4). The coproduct credit for cattle feeding operations benefits from both energy savings when WDGS are used in place of DDGS, and also from improved cattle performance when cattle are fed WDGS, which converts to body weight more efficiently than DDGS (Klopfenstein et al., 2008).

Six percent more beef can be produced per unit WDGS dry matter than when DDGS is fed-this improves the corn and urea replacement values of WDGS relative to DDGS. In addition, cattle fed WDGS require $11 \%$ fewer days on feed to reach market weight than corn-fed cattle and $4 \%$ fewer days than DDGS-fed cattle. Hence, cattle on diets with WDGS emit less methane during their life cycle in the feedlot than DDGS-fed cattle. The differences between WDGS and DDGS account for an improvement in overall feedlot energy credit of $8 \%$ and a $\mathrm{CO}_{2}$ e emissions reduction of $15 \%$.

Feeding DDGS to cattle rather than swine or dairy will result in 53\% greater reduction in GHG emissions. These savings would be even larger if the comparison was between WDGS for beef production and DDGS for swine or poultry (Table 4). Based on these results, general relationships were estimated for coproduct emissions reductions in relation to the proportion of DGS fed wet vs. dry, and to cattle vs. dairy and swine (Fig. 2A). The previously mentioned differences in GHG credit due to use of WDGS vs. DDGS do not include the benefit of $41 \%$ less energy input and $29 \%$ less $\mathrm{CO}_{2}$ e emissions at the biorefinery to produce WDGS instead of DDGS.

\section{Projected Trends in Coproduct Feeding}

Future growth of the corn-ethanol industry will support more widespread adoption of coproduct feeding for livestock. We evaluated several plausible future feeding scenarios to determine the impact of expected changes in feeding practices on coproduct credits. If current DGS use in the livestock industry was increased to the maximum dietary inclusion level without negative impact on animal performance for each animal class, and holding total animal numbers constant, the amount of Corn Belt DGS demand could more than double to 11.3 million Mg DGS annually (dry matter basis, Table 2). If all Midwest livestock producers converted to feeding DGS based diets at maximum inclusion levels, the fed livestock would

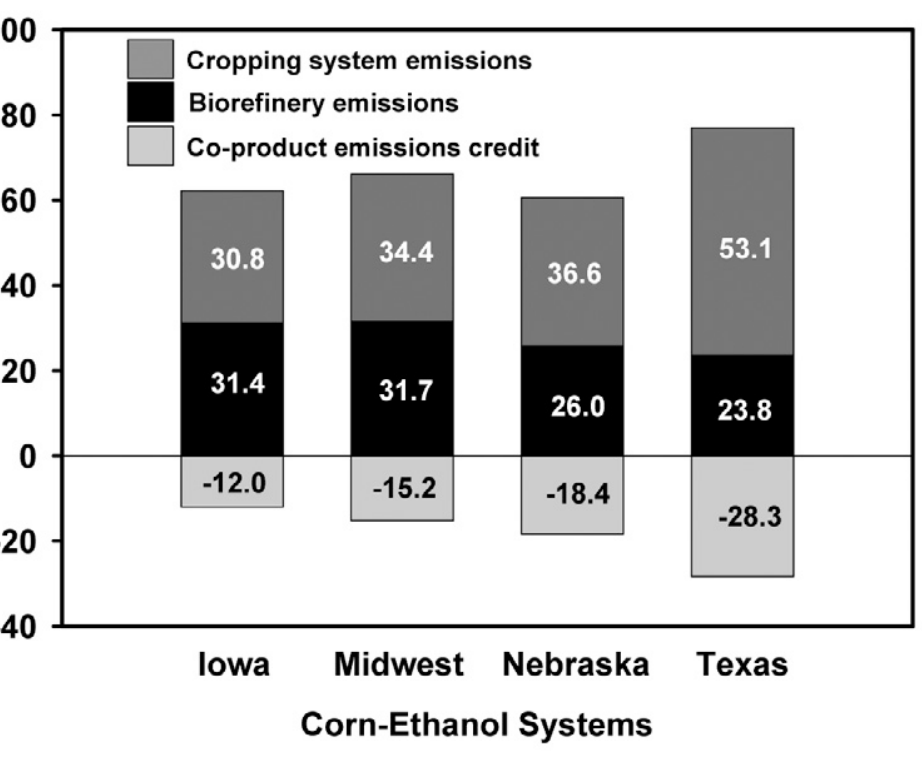

g. 1. Emissions intensities of life cycle components (crop, biorefinery, and coprodt credit) for average coproduct production and livestock feeding practices in wa, Midwest, Nebraska, and Texas (selected scenarios from Table 4). The coprodrequire an ethanol production capacity of 30 billion liters per year (bly). Extrapolating these Midwest DGS use estimates to the entire United States, and assuming that $100 \%$ of U.S. beef cattle, dairy cattle, and grow-finish pigs are fed at maximum inclusion levels, the dairy cattle industry becomes the largest consumer of DGS, and total DGS demand would require coproducts from production of 69 bly. Current U.S. annual corn-ethanol production capacity is about 40 bly (Renewable Fuels Association, 2009), which indicates that U.S. livestock producers could use 1.7 times the amount of the DGS currently produced. If all coproducts were fed at maximum biological inclusion levels, the average coproduct credit would decrease for the ethanol industry from 14.6 to $13.9 \mathrm{gCO}_{2} \mathrm{e}$ $\mathrm{MJ}^{-1}$ (MWfav, Table 4).

\section{Greenhouse Gas Emissions Credits in the Corn-Ethanol Life Cycle}

To evaluate the impact of coproduct credits on the complete corn-ethanol life cycle, we assessed GHG emissions based on the performance of a standard natural gas-powered dry mill (Table 3). Average energy use by the surveyed biorefineries $\left(7.7 \mathrm{MJ} \mathrm{L}^{-1}\right)$ is similar to the average energy use by the majority of natural gas powered dry mills currently operating in the Midwest (Liska et al., 2009). Production of only WDGS was estimated to require only $4.91 \mathrm{MJ}$ $\mathrm{L}^{-1}$, while DDGS production requires $8.33 \mathrm{MJ} \mathrm{L}^{-1}$ due to drying (Tables 3 and 4). Biorefinery parameters (yield, natural gas efficiency, electricity efficiency) for individual facilities based on survey data and average coproduct production rates were used to determine GHG emissions for each biorefinery (MWavg, Table 4). The Midwest average corn-ethanol production system was found to have an average GHG-intensity of $52.2 \pm 2.8 \mathrm{gCO}_{2} \mathrm{e} \mathrm{MJ}^{-1}$ (coefficient of variation of 0.05 ) and a $\mathrm{GHG}$ reduction compared to gasoline of $46.5 \pm 2.8 \%(\mathrm{CV}=0.06)$. 
A)

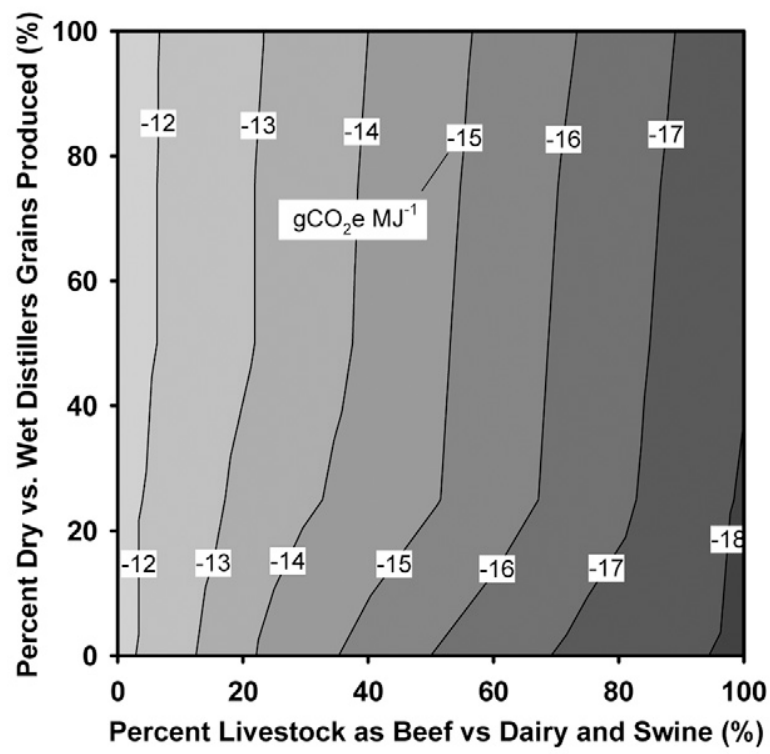

B)

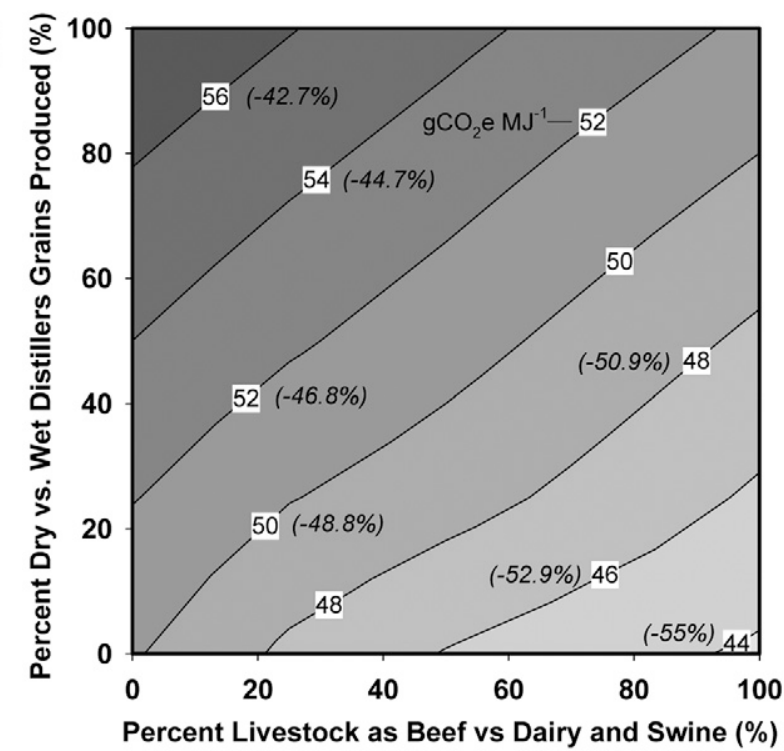

Fig. 2. (A) Coproduct greenhouse gas emissions credit isoquant lines and (B) corn-ethanol life cycle emissions intensity relative to the percentage of coproduct fed to beef livestock (as opposed to dairy and swine, divided equally) vs. the percentage of distillers grains produced dry (as opposed to modified wet and wet distillers grains plus solubles [DGS], divided equally); $100 \%$ ( $x$ axis) is beef and $100 \%$ ( $y$ axis) is dry DGS. Simulations are based on average Midwest corn production scenario in BESS 2009.4.0 (www.bess.unl.edu). Corn-ethanol GHG reduction percentages compared to gasoline $\left(97.7 \mathrm{gCO}_{2} \mathrm{e} \mathrm{MJ}-1\right)$ are shown in parentheses (Liska and Perrin, 2009).

Coproduct credits for the 12 feeding scenarios above were modeled as a component of a standard dry-mill natural gas biorefinery to estimate net life cycle emissions (Table 4). The coproduct credit for the Midwest average scenario (MWavg) offset $23 \%$ of life cycle emissions (Table 5). Regional differences in GHG emissions associated with crop production, and the proportions of coproduct fed to cattle vs. dairy and swine, result in a wide range in the coproduct credit. In Texas, for example, most of the DGS is fed to cattle and the GHG intensity of corn production is high resulting in a coproduct offset credit that represents $37 \%$ life cycle emissions (Fig. 1). Based on model simulations, increasing the proportion of DGS fed to beef cattle relative to other livestock types, and producing more WDGS relative to DDGS, will result in a decrease in net life cycle GHG emissions from roughly 56 to $44 \mathrm{gCO}_{2} \mathrm{e} \mathrm{MJ}^{-1}$, and resulting emissions reductions compared to gasoline increase from 43 to $55 \%$ (Fig. 2B).

\section{Discussion}

A dynamic cattle feeding model was developed to assess the impact of DGS processing and feeding options on net changes in energy requirements and GHG emissions for corn-ethanol systems associated with beef, dairy, and swine production. This analysis estimated a coproduct credit based on updated feeding practices and evaluated the most sensitive factors affecting the magnitude of the credit. The Midwest average GHG credit was $15.2 \mathrm{gCO}_{2}$ e per MJ of ethanol. In previous studies this value has ranged from 17 to $25 \mathrm{gCO}_{2} \mathrm{e} \mathrm{MJ}{ }^{-1}$ (Liska et al., 2009; Farrell et al., 2006; Wang, 1999). The average value we report here is smaller than these previous estimates because we include coproduct fed to dairy and swine, which are less efficient users of coproduct. In addition, our analysis uses a different distribution of coproduct types produced and livestock classes fed based on the most recent data available for actual usage. The GHG credit we estimate is further reduced by variability in upstream emission factors which, for some parameters, may be relatively conservative in BESS compared to the Greenhouse Gases, Regulated Emissions, and Energy Use in Transportation (GREET) model (Liska and Cassman, 2009).

Marginal $\mathrm{N}_{2} \mathrm{O}$ emissions due to coproduct feeding from animal manure $\mathrm{N}$ loss, field application of manure, and $\mathrm{N}_{2} \mathrm{O}$ evolution from indirect atmospheric $\mathrm{N}$ deposition were not evaluated in this study, and they may impact the coproduct GHG credit (IPCC, 2006). The range in parameter values reported by the IPCC for these factors is quite large and environmentally dependent. Further research and evaluation are needed to accurately incorporate these parameters into the coproduct credit model for each livestock class.

We show that current U.S. livestock numbers have the capacity to fully use DGS production from current cornethanol production capacity as well as the expected increase in capacity to 57 bly as mandated under the Energy Independence and Security Act of 2007. This would justify use of the full coproduct credit for all U.S. corn-ethanol production under this mandate.

In conclusion, accurate estimates of net GHG emissions from biofuel systems are critical for estimating the anthropogenic impact of biofuel production on the atmosphere. The coproduct GHG credit represents a large portion of total direct emissions in the corn-ethanol life cycle. Our analysis documents substantial variation in the magnitude of energy intensity and GHG credits associated with coproduct use in corn-ethanol systems and contributes to improved understanding of the factors responsible for this variation. Given the need to assess GHG emissions of biofuel systems as mandated under the renewable fuel standard of the 2007 EISA, it is clear that the accuracy of these assessments can be improved with specification of DGS use in terms of processing and use by different livestock classes. The revised BESS model with the new coproduct scenarios can be used to perform such an LCA. More 
complete data on the types of coproducts produced and use of coproducts by livestock animal class at state and national levels would further improve estimates of the coproduct credit and life cycle GHG emissions from U.S. corn ethanol.

\section{Acknowledgments}

The authors thank the Nebraska Department of Environmental Quality for use of industry data. Funding support for this research came from: (i) the Nebraska Center for Energy Sciences Research at the University of Nebraska-Lincoln (www.ncesr.unl.edu), (ii) the Agricultural Research Division at the University of Nebraska-Lincoln, and (iii) USDA-CSREES NC506 Regional Research.

\section{References}

Anderson, J.L., D.J. Schingoethe, K.F. Kalscheur, and A.R. Hippen. 2006. Evaluation of dried and wet distillers grains included at two concentrations in the diets of lactating dairy cows. J. Dairy Sci. 89:3133-3142.

Arora, S., M. Wu, and M. Wang. 2008. Update of distillers grains displacement ratios for corn ethanol life-cycle analysis. Center for Transportation Research, Energy System Division, Argonne Natl. Lab., Argonne, IL.

Farrell, A.E., R.J. Plevin, B.T. Turner, A.D. Jones, M. O'Hare, and D.M. Kammen. 2006. Ethanol can contribute to energy and environmental goals. Science 311:506-508.

Galyean, M.L., and J.F. Gleghorn. 2001. Summary of the 2000 Texas Tech University consulting nutritionist survey. Burnett Center Internet Progress Rep.12. Available at http://www. asft.ttu.edu/burnett_center/progress_reports/bc12.pdf (verified 18 Nov. 2009). Dep. of Anim. and Food Sci., Texas Tech Univ., Lubbock.

Graboski, M.S. 2002. Fossil energy use in the manufacture of corn ethanol. Natl. Corn Growers Assoc., Chesterfield, MO.

Hill, J., E. Nelson, D. Tilman, S. Polasky, and D. Tiffany. 2006. Environmental, economic, and energetic costs and benefits of biodiesel and ethanol biofuels. Proc. Natl. Acad. Sci. USA 103:11206-11210.

IPCC. 2006. 2006 IPCC Guidelines for national greenhouse gas inventories. Prepared by H.S. Eggleston, L. Buendia, K. Miwa, T. Ngara, and K. Tanabe. Natl. Greenhouse Gas Inventories Programme. IGES, Hayama, Japan.

Janicek, B.N., P.J. Kononoff, A.M. Gehman, and P.H. Doane. 2008. The effect of feeding dried distillers grains plus solubles on milk production and excretion of urinary purine derivatives. J. Dairy Sci. 91:3544-3553.

Kim, S., and B.E. Dale. 2002. Allocation procedure in ethanol production system from corn grain: I. System expansion. Int. J. Life Cycle Assess. 7:237-243.

Kleinschmit, D.H., D.J. Schingoethe, K.F. Kalscheur, and A.R. Hippen. 2006. Evaluation of various sources of corn dried distillers grains plus solubles for lactating dairy cattle. J. Dairy Sci. 89:4784-4794.

Klopfenstein, T.J., G.E. Erickson, and V.R. Bremer. 2008. Use of distillers co-products in diets fed to beef cattle. p. 5-55. In B.B. Babcock et al. (ed.) Using distillers grains in the U.S. and international livestock and poultry industries. Available at http://www.matric.iastate.edu/DGbook/ (verified 18 Nov. 2009). MATRIC, Iowa State Univ. Ames.

Kodera, K. 2007. Analysis of allocation methods of bioethanol LCA. Master's thesis. Vrije Univ., Amsterdam, the Netherlands.

Lain, J., D. Strohbehn, D. DeWitt, R. Euken, and D. Schwab. 2008. A producer survey of feeding corn co-products in Iowa. Animal Industry Rep., A.S. Leaflet R2293. Iowa State Univ., Ames.

Leonardi, C., S. Bertics, and L.E. Armentano. 2005. Effect of increasing oil from distillers grains or corn oil on lactation performance. J. Dairy Sci. $88: 2820-2827$.

Liska, A.J., and K.G. Cassman. 2009. Response to Plevin: Implications for life cycle emissions regulations. J. Ind. Ecol. 13:508-513.

Liska, A.J., and R.K. Perrin. 2009. Indirect land use emissions in the life cycle of biofuels: Regulations vs. science. Biofuels Bioproducts Biorefining 3:318-328.

Liska, A.J., H.S. Yang, V.R. Bremer, T.J. Klopfenstein, D.T. Walters, G.E.
Table 5. Greenhouse gas (GHG) emissions inventory of the corn-ethanol life cycle for a new natural gas dry mill biorefinery in U.S. Midwest (MWavg, Table 4).

\begin{tabular}{|c|c|c|c|}
\hline Component & $\begin{array}{l}\text { GHG emission } \\
\text { category }\end{array}$ & $\mathrm{gCO}_{2} \mathrm{e} \mathrm{MJ}^{-1}$ & $\begin{array}{l}\text { Percent of } \\
\text { life cycle }\end{array}$ \\
\hline \multirow[t]{15}{*}{ Crop production } & Nitrogen fertilizer, $\mathrm{N}$ & 4.44 & 6.71 \\
\hline & Phosphorus fertilizer, $\mathrm{P}_{2} \mathrm{O}_{5}$ & 1.01 & 1.53 \\
\hline & Potassium fertilizer, $\mathrm{K}_{2} \mathrm{O}$ & 0.53 & 0.80 \\
\hline & Lime & 6.59 & 10.0 \\
\hline & Herbicides & 1.77 & 2.68 \\
\hline & Insecticides & 0.075 & 0.114 \\
\hline & Seed & 0.086 & 0.131 \\
\hline & Gasoline & 0.520 & 0.787 \\
\hline & Diesel & 2.32 & 3.51 \\
\hline & LPG & 0.895 & 1.35 \\
\hline & Natural gas & 0.423 & 0.640 \\
\hline & Electricity & 0.923 & 1.40 \\
\hline & Depreciable capital & 0.276 & 0.418 \\
\hline & $\mathrm{N}_{2} \mathrm{O}$ emissions $\dagger$ & 14.5 & 22.0 \\
\hline & Total & 34.4 & 52.0 \\
\hline \multirow[t]{6}{*}{ Biorefinerył } & Natural gas input & 13.8 & 20.8 \\
\hline & Natural gas input: drying DGS & 7.88 & 11.9 \\
\hline & Electricity input & 7.52 & 11.4 \\
\hline & Depreciable capital & 0.454 & 0.7 \\
\hline & Grain transportation & 2.09 & 3.2 \\
\hline & Total & 31.7 & 48.0 \\
\hline \multirow[t]{6}{*}{ Coproduct credit } & Diesel & 0.095 & 0.144 \\
\hline & Urea production & -1.60 & -2.42 \\
\hline & Corn production & -9.64 & -14.6 \\
\hline & Enteric fermentation- $\mathrm{CH}_{4}$ & -1.27 & -1.92 \\
\hline & Soybean production & -2.82 & -4.3 \\
\hline & Total & -15.2 & -23.1 \\
\hline \multicolumn{2}{|c|}{ Transportation of ethanol from biorefinery } & 1.40 & \\
\hline \multicolumn{2}{|c|}{ Life cycle net GHG emissions } & 52.3 & $100 \%$ \\
\hline \multicolumn{2}{|c|}{ GHG-intensity of gasoline, $\S$ gCO2e $\mathrm{MJ}^{-1}$} & 97.7 & \\
\hline \multicolumn{2}{|c|}{ GHG reduction relative to gasoline, $\%$} & 46.5 & \\
\hline
\end{tabular}

† Includes emissions from $\mathrm{N}$ inputs (synthetic fertilizer, manure $\mathrm{N}$ ) and $\mathrm{N}$ losses

(volatilization, leaching/runoff, crop residue) (BESS User's Guide for details); roughly $1.8 \%$ of applied synthetic $\mathrm{N}$ is lost as $\mathrm{N}_{2} \mathrm{O}$ (IPCC, 2006).

Biorefinery performance is based on data in Table 3 .

$\$ 100 \%$ pure petroleum-based gasoline, containing a tar sands fraction (Liska and Perrin, 2009).

Erickson, and K.G. Cassman. 2009. Improvements in life cycle energy efficiency and greenhouse gas emissions of corn-ethanol. J. Ind. Ecol. 13:58-74.

Loomis, R.S., and D.J. Connor. 1998. Crop ecology: Productivity and management in agricultural systems. Cambridge Univ. Press., Cambridge, UK.

NASS. 2007. Ethanol co-products used for livestock feed. Natl. Agric. Statistics Service, Washington, DC.

NASS. 2008. U.S. livestock industry statistics. Available at http://www. nass.usda.gov (verified 18 Nov. 2009). Natl. Agric. Statistics Service, Washington, DC.

NASS. 2009. 2007 Census of agriculture. Natl. Agric. Statistics Service, Washington, DC.

Nebraska Corn Board. 2008. 2007-2008 Nebraska corn quality report. Nebraska Corn Board, Lincoln.

Nichols, J.R., D.J. Schingoethe, H.A. Maiga, M.J. Brouk, and M.S Piepenbrink. 1998. Evaluation of corn distillers grains and ruminally protected lysine and methionine for lactating dairy cows. J. Dairy Sci. $81: 482-491$.

NRC. 1996. Nutrient requirements of beef cattle. 7th ed. Natl. Res. Council, Washington, DC.

NRC. 2000. Nutrient requirements of beef cattle: Update 2000. 7th revised 
ed. Natl. Res. Council, Washington, DC.

Perrin, R.K., N.F. Fretes, and J.P. Sesmero. 2009. Efficiency in Midwest US corn ethanol plants: A plant survey. Energy Policy 37:1309-1316.

Renewable Fuels Association. 2009. Growing innovation: Ethanol industry outlook 2009. Renewable Fuels Assoc., Washington, DC.

Schingoethe, D. 2008. Use of distillers co-products in diets fed to dairy cattle. p. 57-78. In B.B. Babcock et al. (ed.) Using distillers grains in the U.S. and international livestock and poultry industries. Available at http:// www.matric.iastate.edu/DGbook/ (verified 18 Nov. 2009). MATRIC Iowa State Univ. Ames.

Schingoethe, D.J., M.J. Brouk, and C.P. Birkelo. 1999. Milk production and composition from cows fed wet corn distillers grains. J. Dairy Sci. 82:574-580.

Stein, H.H. 2007. Distillers dried grains with solubles (DDGS) in diets fed to swine. HHS-SwineFocus-001. Dep. of Animal Sciences, Univ. of Illinois, Champaign-Urbana.
Stein, H.H. 2008. Use of distillers co-products in diets fed to swine. p. 7997. In B.B. Babcock et al. (ed.) Using distillers grains in the U.S. and international livestock and poultry industries. Available at http://www. matric.iastate.edu/DGbook/ (verified 18 Nov. 2009). MATRIC Iowa State Univ., Ames.

Vasconcelos, J.T., and M.J. Galyean. 2007. Nutritional recommendations of feedlot consulting nutritionists: The 2007 Texas Tech University survey. J. Anim. Sci. 85:2772-2781.

Wang, M.Q. 1999. GREET 1.5-Transportation fuel-cycle model volume 1: Methodology, development, use, and results. ANL/ESD-39. Vol. 1. Ctr. for Transportation Res., Energy Systems Div., Argonne Natl. Lab.

Waterbury, J.A., D.R. Mark, R.K. Perrin., S.M. Thoms, G.E. Erickson., and T.K. Klopfenstein. 2009. Results of the ethanol co-product survey: An economic overview of ethanol co-product utilization in Nebraska. MP 92. Univ. of Nebraska. Lincoln. 